\title{
TRANSFORAMINAL INTERSOMATIC LUMBAR ARTHRODESIS: COMPARISON BETWEEN AUTOGRAFT AND CAGE IN PEEK
}

\section{ARTRODESE LOMBAR INTERSOMÁTICA TRANSFORAMINAL: COMPARADO AUTOENXERTO E CAGE-PEEK}

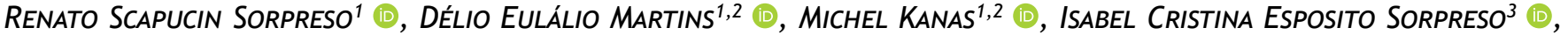 \\ NELSON ASTUR ${ }^{2,4}$ (1), MARCELO WAJCHENBERG ${ }^{1,2}$ (i)
}

1. Universidade Federal de São Paulo, Paulista School of Medicine, Sports Traumatology Center, São Paulo, SP, Brazil.

2. Hospital Israelita Albert Einstein, São Paulo, SP, Brazil.

3. Universidade de São Paulo, Medical School, São Paulo, SP, Brazil.

4. Santa Casa de São Paulo, Department of Orthopedics and Traumatology “Fernandinho Simonsen Pavilion", São Paulo, SP, Brazil.

\section{ABSTRACT}

Objective: To compare the postoperative outcomes of transforaminal intersomatic lumbar arthrodesis with structured iliac bone autograft and PEEK device. Methods: The total of 93 medical records of patients undergoing transforaminal intersomatic fusion between January 2012 and July 2017 with at least 1 year of postoperative follow-up, with complete medical record, containing clinical file and radiological exams, were reviewed. Results: From the medical records evaluated, 48 patients underwent the procedure with structured iliac autograft (group 1) and 45 with PEEK device (group 2). There was an improvement in functional capacity in both groups $(p<0.001)$, however there was no difference when comparing them $(p=0.591)$. Conclusion: The postoperative clinical and radiological results of lumbar arthrodesis with TLIF technique, using a structured iliac bone autograft compared to a PEEK device, were similar. Level of Evidence II, Retrospective study.

Keywords: Spinal Fusion. Laminectomy. Intervertebral Disc Degeneration.

\section{RESUMO}

Objetivo: Comparar os desfechos pós-operatórios da artrodese lombar intersomática transforaminal com autoenxerto ósseo ilíaco estruturado e dispositivo em poliéter-éter-cetonico-polímero (PEEK). Métodos: Foram revistos 93 prontuários de pacientes submetidos à fusão intersomática transforaminal entre janeiro de 2012 e julho de 2017 com pelo menos um ano de acompanhamento pós-operatório, com prontuário completo, contendo ficha clínica e exames radiológicos. Resultados: Dos prontuários avaliados, 48 pacientes foram submetidos ao procedimento com autoenxerto ilíaco estruturado (Grupo 1) e $45 \mathrm{com}$ dispositivo em PEEK (Grupo 2). Houve meIhora da capacidade funcional em ambos os grupos $(p<0,001)$, no entanto não houve diferença ao compará-los $(p=0,591)$. Conclusão: Os resultados clínicos e radiológicos pós-operatórios da artrodese lombar na técnica Fusão Intersomática Lombar Transforaminal (TLIF) utilizando autoenxerto ósseo ilíaco estruturado, em comparação com o uso de dispositivo em PEEK, foram semelhantes. Nível de Evidência II, Estudo retrospectivo.

Descritores: Fusão Vertebral. Laminectomia. Degeneração do Disco Intervertebral.

Citation: Sorpreso RS, Martins DE, Kanas M, Sorpreso ICE, Astur N, Wajchenberg M. Transforaminal intersomatic lumbar artrodesis: comparison autograft and cage in PEEK. Acta Ortop Bras. [online]. 2020;28(6):296-302. Available from URL: http://www.scielo.br/aob.

\section{INTRODUCTION}

Spinal disorders are among the most common problems encountered in clinical practice, ${ }^{1}$ affecting up to $80 \%$ of the population at some point in life. ${ }^{2}$ Lumbar arthrodesis is used as a treatment alternative for patients with degenerative discopathies, spondylolisthesis, segmental instabilities, among others. ${ }^{1,3}$ It may or may not be associated with instrumentation, being subdivided depending on its approach such as: posterior fusion (PF), posterolateral fusion (PLF), anterior lumbar intersomatic fusion (ALIF), posterior lumbar intersomatic fusion (PLIF), transforaminal lumbar intersomatic fusion (TLIF) and lateral lumbar intersomatic fusion (LLIF). ${ }^{1,3}$
The association of PLF with pedicular instrumentation presents consolidation levels of up to $92 \%{ }^{4,5}$ Including the intersomatic technique, it reaches rates of $96 \%$ in the case of PLIF associated with transpedicular fixation. ${ }^{5-7}$ PLIF requires major retraction of the dural sac and nerve roots, increasing the risk of dural injury and root injury. ${ }^{8}$ The transforaminal technique (TLIF) brought less manipulation of neural structures with unilateral access to the disc space, becoming the most used technique for lumbar degenerative disorders. ${ }^{9}$ The theoretical advantages of TLIF over PLF include anterior spine support, indirect foraminal decompression, removal of the disc as a pain generator, and restoration of lumbar lordosis. ${ }^{9}$

All authors declare no potential conflict of interest related to this article.

The study was conducted at Universidade Federal de São Paulo, Paulista School of Medicine, Sports Traumatology Center.

Correspondence: Renato Scapucin Sorpreso. Rua Estado de Israel, 636, Vila Clementino, São Paulo, SP, Brazil, 04022001. renatosso@yahoo.com 
To perform vertebral fusion, bone graft sums traditionally obtained from the patient's iliac crest, ${ }^{10,11}$ considered the gold standard, which provides mineral architecture for the orientation of bone growth and osteogenic factors. ${ }^{12}$

In this sense, this study aims to analyze clinical and radiographic parameters of patients submitted to lumbar arthrodesis by transforaminal technique using structured iliac autograft, as well as to compare postoperative clinical and radiographic results after lumbar intersomatic arthrodesis using structured iliac autograft and the PEEK device.

\section{MATERIALS AND METHODS}

The study was approved by the Research Ethics Committee under Protocol No. 1342, in 2017. All participants signed an informed consent form. Data from medical records from 2012 to 2016 from the database of a private hospital were included, where a search was performed for patients submitted to transforaminal intersomatic lumbar arthrodesis, of both genders, over 18 years of age, for the treatment of lumbar degenerative disease, such as spondylolistesis, degenerative disease of the vertebral canal and spinal canal stenosis. As inclusion criteria, patients should have all been operated by the same surgical team, have intersomatic arthrodesis by transforaminal access of one or two vertebral levels, complete follow-up with medical records, imaging exams and questionnaires routinely applied by the group before and after the surgical procedure. Lumbar arthrodesis is indicated by the group in the presence of degenerative disease of the lumbar spine with segmental instability, previously submitted to clinical treatment for at least six months in the absence of neurological urgency. The medical records of individuals with active neoplastic or infectious disease, scoliosis with angulation greater than $15^{\circ}$ and surgeries of three or more lumbar levels were excluded.

The patients were grouped as follows: Group 1 (structured iliac bone autograft, Figure 1) and Group 2 (PEEK device, Figure 2) according to the description of the surgical technique.

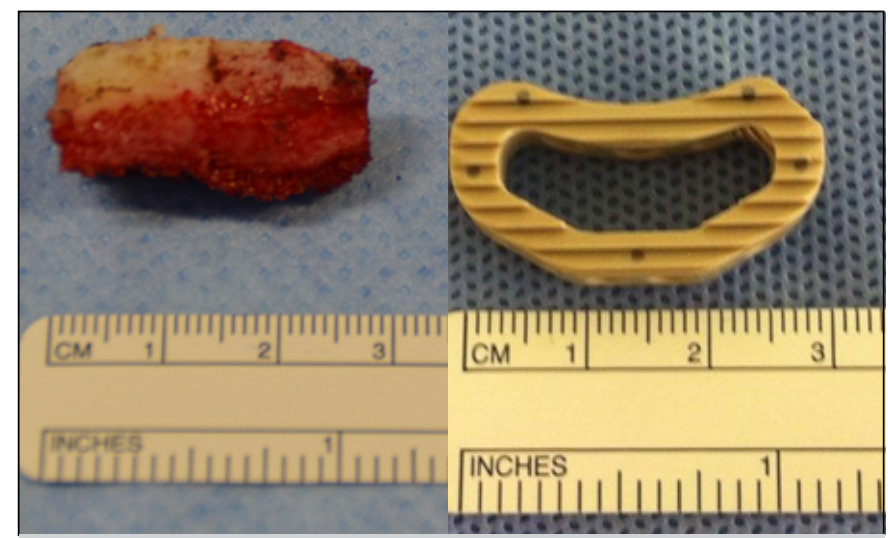

Figure 1. Photographs of the structured iliac graft and the spacer in polyether-ether-ketone polymer, demonstrating measurement of the laterolateral diameter, 2016.

All patients were submitted to antibiotic prophylaxis, performed according to the Hospital Infection Control Service $(\mathrm{SCIH})$. Analgesia and postoperative standard rehabilitation.

All participants completed a socio-demographic and clinical form (age, gender, morbidity, smoking habit, time of clinical treatment, work activity, sports practice and time away from work), and completed the Oswestry Disability Index (ODI) dysfunction questionnaire in the version validated for Portuguese before and after 12 months of the surgical procedure. ${ }^{13}$

Acta Ortop Bras. 2020;28(6):296-302

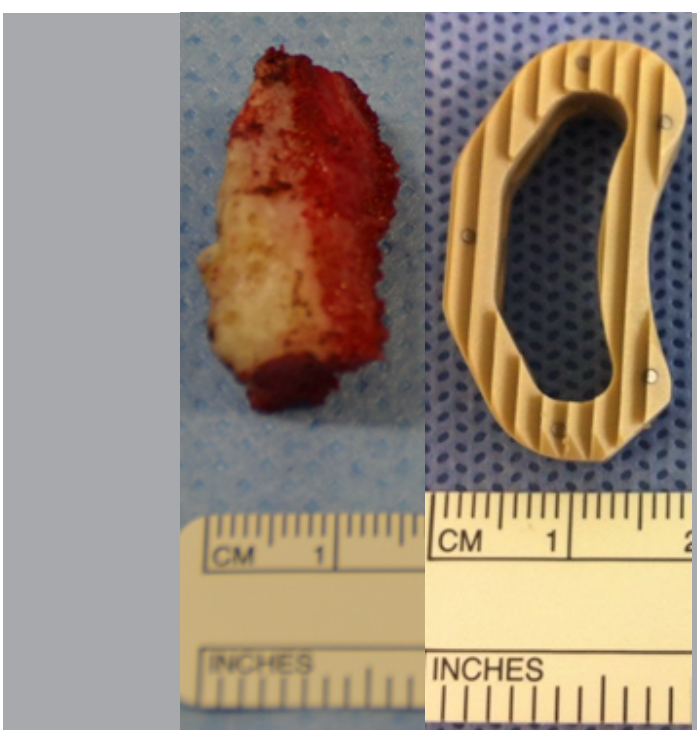

Figure 2. Photographs of the structured iliac graft and spacer in polyether-ether-ketone polymer, demonstrating measurement of the anteroposterior diameter, 2016

Before surgery, patients underwent simple radiographs and MRI scans in the anteroposterior and lateral positions, as well as the lateral position with maximum flexion and extension. The scale of Pfirrmann et al. ${ }^{14}$ was used. for classification of disc degeneration. The determination of muscle strength was according to the Medical Research Council scale for manual motor tests. ${ }^{15}$ Radiological measurements were carried out before the surgery and one-year after it, through the Software Surgimap ${ }^{\circledR}$ and Easy Pixel Too ${ }^{\circledR}$ version 1.1 (for OSX 10.8 processor or later 64 -bit). For the height of the intervertebral disc, the modified Farfan classification was used. ${ }^{16}$ The angle of the intervertebral disc and lumbar lordosis were measured according to Cobb's method (1948). ${ }^{17}$ For radiographic evaluation of fusion, criteria of the Food and Drug Administration Center for Devices and Radiological Health (FDA) were used, in which fusion is defined as angular motion smaller than five degrees and sagittal movement on dynamic radiographs less than three millimeters. ${ }^{18}$

\section{Surgical technique}

Performed by paramedian surgical access. ${ }^{19-21}$ Single incision in the skin, subcutaneous divulsion, removal of iliac bone graft including the anterior-superior iliac spine (right or left) totaling 2 or $2.5 \mathrm{~cm}$ of craniocaudal extension. The latero-medial size was the thickness of the iliac of the patient and a depth of $0.5 \mathrm{~cm}$, so that muscle disinsertion was not performed, and the limits of the sacroiliac joint were respected. Removal of iliac spongy graft. The back-loin fascia was sutured along with the subcutaneous. We carried out the incision of two access routes in the back plate fascia, as well as muscle digitodivulsion, installation of polyaxial pedicular screws in $L 4$ to S1 or L5-S1, hemyloaminectomy(s) of the most symptomatic side and facetectomies, transforaminal access to the disc, preparation of terminal plates and partial filling of the disc space (anterior to the intersomatic device) with iliac spongy bone graft.

Group 1: Manual preparation of the iliac bone autograft structured by additional osteotomies with a gouge, respecting the height of the disc space observed intraoperatively. Introduction by annullotomy by intersomatic positioning in the middle third of the vertebral bodies under traction, without intersomatic compression before torque in the fixation system.

Group 2: Measurement of the height of the intraoperative disc space under traction of the screws to determine the size of the 
device. Introduction by annullotomy by positioning it intersomatic in the middle third of the vertebral bodies under traction, without intersomatic compression before torque in the fixation system. As shown in Figure 3:

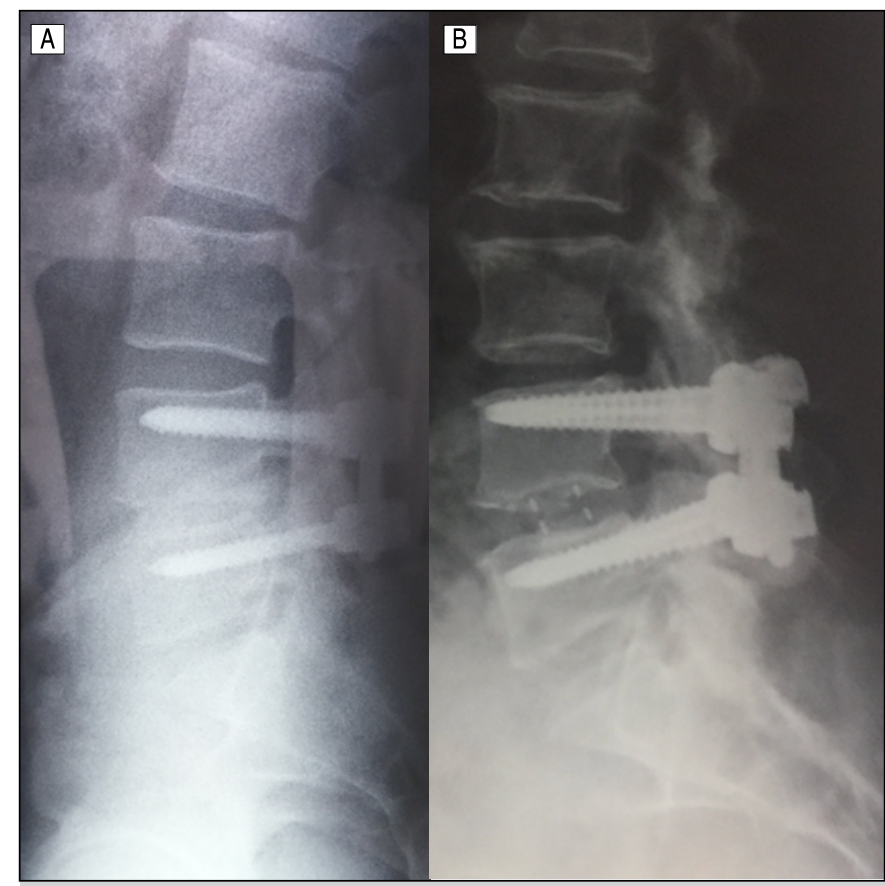

Figure 3. X-ray images of the lumbosacral spine in orthostatic profile illustrating intersomatic arthrodesis with structured iliac auto graft $(A)$ and intersomatic device in PEEK (B), 2016.

\section{Statistical analysis}

Qualitative variables were presented by absolute and relative frequencies, while quantitative variables were presented by measures of central tendency and respective confidence intervals of $95 \%$. To analyze the adherence of the data to the normal distribution, the Shapiro-Wilk test was used. In the associations between the qualitative variables, the chi-square test with Yates correction was used. For the analysis of the magnitude of the associations, we used Poisson regression with robust variance, estimating the prevalence ratio and respective confidence intervals of $95 \%$, adjusted for the variables that presented association.

The quantitative variables with symmetric distribution were compared by Student's t-test for independent samples. The Mann-Whitney test was used for variables without normal distribution. To compare the differences in the pre- and postoperative moments, Student's t-test was used for paired samples. Linear Regression was used to estimate the effects of surgical techniques on height and disc angulation and lumbar lordosis between the groups at the moments studied. For all analyses, a $5 \%$ significance level was adopted. The program used was Stata $^{\circledR}$ (StataCorp., LC) 11.0

\section{RESULTS}

After establishment of the inclusion criteria, we selected 93 patients treated with intersomatic arthrodesis of the lumbar spine by structured iliac bone autograft or peek device and their medical records were reviewed. Sociodemographic and clinical characteristics are described in Table 1.
Table 1. Characterization of patients treated with lumbar arthrodesis using transforaminal lumbar intersomatic fusion in polyether-ether-ketone polymer and structured iliac bone autograft, São Paulo, Brazil, 2012-2016.

\begin{tabular}{|c|c|c|}
\hline Variables & $\mathbf{N}$ & $\%$ \\
\hline \multicolumn{3}{|l|}{ Gender } \\
\hline Female & 40 & 43 \\
\hline Male & 53 & 57 \\
\hline \multicolumn{3}{|l|}{ Number of Affected Locations } \\
\hline 1 location & 63 & 67.7 \\
\hline 2 locations & 30 & 32.3 \\
\hline Comorbidities & 5 & 18.5 \\
\hline Smoking habit & 26 & 28.3. \\
\hline \multicolumn{3}{|l|}{ Physical Activity } \\
\hline Preoperative & 37 & 40.2 \\
\hline Post-operative & 48 & 52.2 \\
\hline Employment & 83 & 90.2 \\
\hline \multicolumn{3}{|l|}{ Pfirrmann } \\
\hline III & 7 & 5.4 \\
\hline IV & 116 & 89.9 \\
\hline $\mathrm{V}$ & 6 & 4.7 \\
\hline \multicolumn{3}{|l|}{ Pathologies } \\
\hline Degenerative discopathy with compression & 58 & 62.4 \\
\hline Degenerative discopathy without compression & 6 & 6.3 \\
\hline Spondylolisthesis & 18 & 19.4. \\
\hline Central stenosis & 1 & 1.1 \\
\hline Pseudoarthrosis & 9 & 9.7 \\
\hline Synovial cyst & 1 & 1.1 \\
\hline Strength deficit & 59 & 63.4 \\
\hline \multicolumn{3}{|l|}{ Operated level } \\
\hline \multicolumn{3}{|l|}{ L3-L4 } \\
\hline L4-L5 & 15 & 16.1 \\
\hline L5-S1 & 28 & 30.1 \\
\hline L3-L4 + L4-L5 & 6 & 6.5 \\
\hline L4-L5 + L5-S1 & 44 & 47.3 \\
\hline \multirow[t]{2}{*}{ Reoperation due to mis-positioning } & 1 & 1.1 \\
\hline & Mean (SD) & (min-max) \\
\hline Age & $43.7(9.0)$ & $27-68$ \\
\hline Time of prior treatment & $16.4(11.2)$ & $4-48$ \\
\hline ODI & $31.5(8.3)$ & $10-50$ \\
\hline
\end{tabular}

SD: standard deviation; min-max.: minimum and maximum values, respectively.

Table 2 compares the preoperative sociodemographic and clinical characteristics of Groups 1 and 2, demonstrating homogeneity, except that physical activity is higher in the group treated with preoperative PEEK device ( $p=0.037)$ and the presence of degenerative discopathy with compression is higher in the group where the autograft was used ( $p=0.016)$.

The preoperative clinical and radiographic characteristics of patients in both groups were similar in terms of the presence of sciatica ( $p=0.683)$, strength deficit $(p=0.126)$, site of injury (L3S1) $(p=0.630)$, functional capacity $(p=0.310)$, lumbar lordosis $(p=0.763)$ and Pfirmann radiological classification $(p=0.617)$, disc height at both level L4-L5 ( $p=0.139)$ and L5-S1 ( $p=0.791)$ and disc angulation $(p=0.283$ and $p=0.719)$. These data showed that there were no differences between the groups for all variables in the preoperative moment (Table 3). 
Table 2. Comparison of sociodemographic and preoperative clinical characteristics of patients treated with lumbar arthrodesis using structured iliac bone autograft and polyether-ether-ketone polymer device.

\begin{tabular}{|c|c|c|c|c|}
\hline \multirow[t]{2}{*}{ Variables } & \multirow{2}{*}{$\begin{array}{c}\mathrm{N} \\
93(100 \%)\end{array}$} & $\begin{array}{c}\text { Graft } \\
(n=48 ; 51.6 \%)\end{array}$ & $\begin{array}{c}\text { PEEK } \\
(n=45 ; 48.4 \%)\end{array}$ & \multirow[t]{2}{*}{$\mathbf{p}^{*}$} \\
\hline & & \multicolumn{2}{|c|}{$\mathrm{n}(\%)$} & \\
\hline Male & $40(43.0)$ & $27(56.2)$ & $26(57.8)$ & 0.882 \\
\hline $\begin{array}{l}\text { More than one } \\
\text { affected location }\end{array}$ & $30(67.7)$ & $13(27.1)$ & $17(37.8)$ & 0.270 \\
\hline Comorbidities & $5(18.5)$ & $4(8.3)$ & $1(2.2)$ & 0.192 \\
\hline Smoking habit & $26(29.3)$ & $14(29.8)$ & $12(26.7)$ & 0.740 \\
\hline $\begin{array}{c}\text { Preoperative } \\
\text { Physical Activity }\end{array}$ & $37(40.2)$ & $14(29.8)$ & $23(51.1)$ & 0.037 \\
\hline Employment & $83(90.2)$ & 44 (93.6) & $39(86.7)$ & 0.262 \\
\hline \multicolumn{5}{|l|}{ Pathologies, n (\%) } \\
\hline DD with compression & 58 & $32(66.7)$ & $26(57.8)$ & \multirow{6}{*}{0.016} \\
\hline DD without compression & 6 & $6(12.5)$ & $0(0.0)$ & \\
\hline Spondylolisthesis & 18 & $9(18.8)$ & $9(20.0)$ & \\
\hline Central stenosis & 1 & $0(0)$ & $1(2.2)$ & \\
\hline Pseudoarthrosis & 9 & $1(2.1)$ & $8(17.8)$ & \\
\hline \multirow[t]{2}{*}{ Synovial cyst } & 1 & $0(0)$ & $1(2.2)$ & \\
\hline & Mean & \multicolumn{2}{|c|}{ Median $(95 \% \mathrm{Cl})$} & $p^{\star *}$ \\
\hline Age (years) & 43.7 & $\begin{array}{c}42.5(39.7 ; \\
46.3)\end{array}$ & $42.0(39.0 ; 47.2)$ & 0.895 \\
\hline $\begin{array}{c}\text { Duration of } \\
\text { pre-operative } \\
\text { treatment (months) }\end{array}$ & 16.4 & $\begin{array}{c}12.0(9.0 \\
-18.0)\end{array}$ & $12.0(12.0-18.0)$ & 0.668 \\
\hline
\end{tabular}

DD: Degenerative discopathy; 95\%Cl: 95\% Confidence Interval; *: Chi-square with Yates correction; **: Mann-Whitney.

Table 3. Comparison of sociodemographic and preoperative clinical characteristics of patients treated with lumbar arthrodesis using structured iliac bone autograft and polyether-ether-ketone polymer device.

\begin{tabular}{|c|c|c|c|}
\hline Variables & $\begin{array}{c}\text { Graft } \\
(51.6 \% ; n=48)\end{array}$ & $\begin{array}{c}\text { PEEK } \\
(48.4 \% ; n=45)\end{array}$ & $\mathbf{p}^{*}$ \\
\hline Sciatica, n (\%) & $39(81.3)$ & $38(84.4)$ & 0.683 \\
\hline Strength deficit, n (\%) & $34(70.8)$ & $25(55.6)$ & 0.126 \\
\hline \multicolumn{4}{|l|}{ Lesion site, $\mathrm{n}(\%)$} \\
\hline L3-L4 & $2(4.2)$ & $1(1.8)$ & \multirow{3}{*}{0.63} \\
\hline L4-L5 & $21(43.7)$ & $29(50.9)$ & \\
\hline L5-S1 & $25(52.1)$ & $27(47.3)$ & \\
\hline \multicolumn{4}{|l|}{ Pfirrmann } \\
\hline III & $3(4.5)$ & $4(6.0)$ & \multirow{3}{*}{0.617} \\
\hline IV & $59(89.4)$ & $57(83.8)$ & \\
\hline V & $4(6.1)$ & $7(10.2)$ & \\
\hline \multicolumn{4}{|l|}{$\begin{array}{l}\text { Oswestry (Disability } \\
\text { classification), } n(\%)\end{array}$} \\
\hline Minimal disability $(0-\mid 20)$ & $0(0.0)$ & $1(2.2)$ & \multirow{5}{*}{0.31} \\
\hline Moderate disability $(21-\mid 40)$ & $1(2.1)$ & $4(8.9)$ & \\
\hline Severe disability $(41-\mid 60)$ & $21(44.7)$ & $18(40.0)$ & \\
\hline Crippled $(61-\mid 80)$ & $15(31.9)$ & $17(37.8)$ & \\
\hline $\begin{array}{c}\text { Bed-bound or exaggerating } \\
\text { symptoms }(80-\mid 100)\end{array}$ & $10(21.3)$ & $5(11.1)$ & \\
\hline
\end{tabular}

Table 3. Comparison of sociodemographic and preoperative clinical characteristics of patients treated with lumbar arthrodesis using structured iliac bone autograft and polyether-ether-ketone polymer device.

\begin{tabular}{|c|c|c|c|}
\hline Variables & $\begin{array}{c}\text { Graft } \\
(51.6 \% ; n=48)\end{array}$ & $\begin{array}{c}\text { PEEK } \\
(48.4 \% ; n=45)\end{array}$ & $\mathbf{p}^{*}$ \\
\hline & \multicolumn{2}{|c|}{ Median $(95 \% \mathrm{Cl})$} & $\mathrm{p}^{\star \star}$ \\
\hline $\begin{array}{l}\text { Lumbar lordosis in degrees of } \\
\text { angulation, mean }(95 \% \mathrm{Cl})\end{array}$ & $53.0(48.6 ; 57.5)$ & $54.1(48.8 ; 59.3)$ & 0.763 \\
\hline \multicolumn{4}{|l|}{$\begin{array}{l}\text { Height of discs in pixels, } \\
\text { average }(95 \% \mathrm{Cl})\end{array}$} \\
\hline L3-L4 & $19.1(14.6 ; 23.5)$ & $27.5^{\star \star \star}$ & - \\
\hline L4-L5 & $22.2(17.6 ; 26.8)$ & $26.3(22.8 ; 28.9)$ & 0.139 \\
\hline L5-S1 & $25.1(20.6 ; 29.6)$ & $24.4(20.8 ; 27.9)$ & 0.791 \\
\hline \multicolumn{4}{|l|}{ Disc angulation, mean $(95 \% \mathrm{Cl})$} \\
\hline L3-L4 & $6.1(-30.7 ; 42.9)$ & $0,2^{* * *}$ & \\
\hline L4-L5 & $6.8(4.7 ; 8.2)$ & $5.3(3.4 ; 7.2)$ & 0.283 \\
\hline L5-S1 & $7.4(5.4 ; 9.4)$ & $7.9(5.9 ; 9.9)$ & 0.719 \\
\hline
\end{tabular}

95\%Cl: $95 \%$ Confidence Interval; *: Chi-square with Yates correction; **: Student's t-test; *: Just one participant.

The postoperative comparison is shown in Table 4. There was no significant difference between the groups in relation to sciatica $(p=0.547)$, improvement of muscle strength $(p=0.0820)$, return to work ( $p=0.472)$, physical activity $(p=0.292)$ and months of absence from social insurance $(p=0.889)$.

Table 4. Comparison of postoperative clinical criteria of patients treated with lumbar arthrodesis with structured iliac bone autograft and the polyether-ether-ketone polymer device.

\begin{tabular}{|c|c|c|c|}
\hline Variables & $\begin{array}{c}\text { Graft } \\
(51.6 \% ; \\
n=48)\end{array}$ & $\begin{array}{c}\text { PEEK } \\
(48.4 \% ; \\
n=45)\end{array}$ & $\mathbf{p}^{*}$ \\
\hline \multicolumn{4}{|l|}{ Sciatica, n (\%) } \\
\hline Stable & $9(18.8)$ & $7(15.6)$ & \multirow{3}{*}{0.547} \\
\hline Improvement & $39(81.2)$ & $37(82.2)$ & \\
\hline Worsening & $0(0)$ & $1(2.2)$ & \\
\hline Analysis of muscle strength, $\mathrm{n}(\%)$ & $34(70.8)$ & $24(53.3)$ & 0.082 \\
\hline Return to work, n (\%) & $37(78.7)$ & $32(71.1)$ & 0.472 \\
\hline \multirow[t]{2}{*}{ Practice of physical activity, n (\%) } & $22(46.8)$ & $26(57.8)$ & 0.292 \\
\hline & & & $\mathbf{p}^{\star *}$ \\
\hline Months of absence, median and $95 \% \mathrm{Cl}$ & $7.0(6.0 ; 9.0)$ & $7.0(6.0 ; 10.8)$ & 0.889 \\
\hline
\end{tabular}

Table 5 shows that the two groups showed significant improvement in the Oswestry index after arthrodesis $(p<0.001)$, and there was no difference when comparing the two techniques $(p>0.05)$. Regarding radiological parameters, there was no significant difference when comparing lordosis, height and pre- and postoperative disc angulation in both groups ( $p>0.05)$.

Figure 4 shows the reduction of functional disability of patients one year after surgery, with no pre- and postoperative differences between them. There was a gain of $81.8 \%$ in patients operated using the technique with structured iliac bone autograft and $75.6 \%$ in patients with the PEEK device. 
Table 5. Clinical and radiological characteristics in the pre- and postoperative period of patients treated with lumbar arthrodesis using structured iliac bone autograft compared to the polyether-ether-ketone polymer device.

\begin{tabular}{|c|c|c|c|c|c|c|c|c|c|c|}
\hline \multirow[t]{2}{*}{ Variables } & \multicolumn{4}{|c|}{$\begin{array}{c}\text { Graft } \\
(51.6 \% ; n=48)\end{array}$} & \multicolumn{4}{|c|}{$\begin{array}{c}\text { PEEK } \\
(48.4 \% ; n=45)\end{array}$} & \multirow{2}{*}{$\begin{array}{l}\text { Postoperative } \\
\text { Difference }\end{array}$} & \multirow[t]{2}{*}{$\mathbf{p}^{* *}$} \\
\hline & Preoperative & Postoperative & Difference & $p^{*}$ & Preoperative & Postoperative & Difference & $p^{*}$ & & \\
\hline $\begin{array}{l}\text { Oswestry (score in } \\
\% \text { mean, } 95 \% \mathrm{Cl} \text { ) }\end{array}$ & 64.7 & 20 & -44.7 & $<0.001$ & 61.2 & 22.3 & -38.9 & $<0.001$ & 5.0 & 0.06 \\
\hline \multirow{2}{*}{$\begin{array}{l}\text { Lumbar lordosis (mean } \\
\text { angulation, } 95 \% \mathrm{Cl} \text { ) }\end{array}$} & 53.5 & 52.9 & -0.58 & \multirow{2}{*}{0.769} & 53.6 & 54.1 & 0.48 & \multirow{2}{*}{0.747} & 2.4 & \multirow{2}{*}{0.38} \\
\hline & $(48.8 ; 58.2)$ & $(48.3 ; 57.5)$ & $(-4.6 ; 3.5)$ & & $(48.3 ; 58.9)$ & $(50.1 ; 58.0)$ & $(-2.5 ; 3.5)$ & & $(-3.2 ; 8.0)$ & \\
\hline \multirow{2}{*}{ L3-L4* } & 19.1 & 13 & -6.1 & \multirow{2}{*}{0.195} & \multirow{2}{*}{27.4} & \multirow{2}{*}{39.3} & \multirow{2}{*}{-11.8} & & \multirow{2}{*}{17.9} & \multirow{2}{*}{-} \\
\hline & $(14.6 ; 23.5)$ & $(-7.0 ; 33.0)$ & $(-30.5 ; 18.4)$ & & & & & & & \\
\hline \multirow{2}{*}{ L4-L5 } & 22.2 & 20.5 & -1.6 & \multirow{2}{*}{0.242} & 27 & 26.5 & -0.5 & \multirow{2}{*}{0.724} & 1.2 & \multirow{2}{*}{0.548} \\
\hline & $(17.6 ; 26.8)$ & $(15.8 ; 25.3)$ & $(-4.4 ; 1.2)$ & & $(23.3 ; 30.6)$ & $(22.7 ; 30.2)$ & $(-3.2 ; 2.2)$ & & $(-2.9 ; 0.9)$ & \\
\hline L5-S1 & 24.5 & 22.6 & -1.8 & 0.29 & 25 & 23.1 & -1.9 & 0.148 & -0.07 & 0.970 \\
\hline L3-L4 $4^{\star \star *}$ & $(-30.7 ; 42.9)$ & $(-10.0 ; 20.4)$ & $(-53.0 ; 51.2)$ & 0.862 & 0.2 & 1.0 & 1.3 & - & -2.2 & 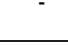 \\
\hline 4 & 6.9 & 7.3 & 0.4 & 0533 & 5.3 & 6.8 & 1.5 & 050 & 1.01 & 0285 \\
\hline L4-LJ & $(4.7 ; 9.0)$ & $(5.7 ; 8.8)$ & $(-0.9 ; 1.7)$ & 0.000 & $(3.4 ; 7.2)$ & $(5.8 ; 7.8)$ & $(-0.1 ; 3.1)$ & 0.005 & $(-0.94 ; 3.2)$ & .200 \\
\hline $5-S 1$ & 7.6 & 9.2 & 1.6 & 007 & 7.4 & 7.6 & 0.2 & 0807 & -1.4 & 0260 \\
\hline ו & $(5.5 ; 9.6)$ & $(7.6 ; 10.7)$ & $(-0.14 ; 3.3)$ & & $(5.6 ; 9.1)$ & $(6.0 ; 9.2)$ & $(-1.6 ; 2.0)$ & & $(-3.9 ; 1.1)$ & \\
\hline
\end{tabular}

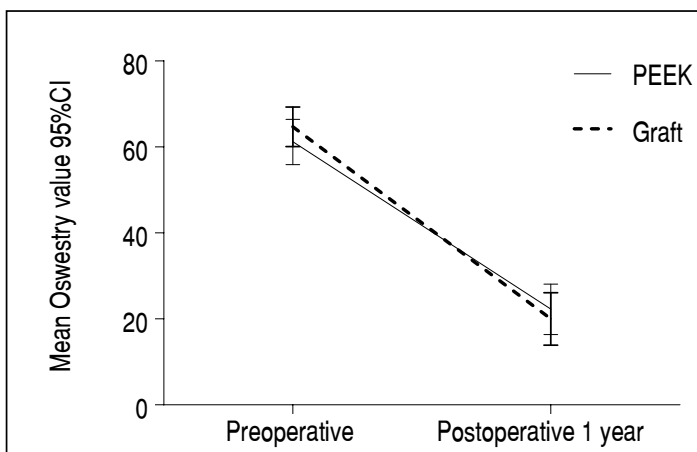

Oswestry variation above $30 \%$, PEEK: $75,6 \%$

Oswestry variation above $30 \%$, Graft: $81.8 \%$

PR: $1.1(95 \% \mathrm{Cl} 0.9 ; 1.3) ; \mathrm{p}^{*}=0.494$

*Poisson regression adjusted for robust variance

Figure 4. Comparison of differences in the percentage of improvement of the Oswestry Disability index of patients in the pre- and postoperative times (one year) treated with lumbar arthrodesis using structured iliac bone autograft and the polyether-ether-ketone polymer device.

\section{DISCUSSION}

The use of the intersomatic device in PEEK in lumbar arthrodesis is related to good results of gain of disc height, lumbar lordosis, improvement of functional capacity and indirect foraminal decompression. However, the main disadvantage is the high cost of the devices, especially for patients from developing countries and regions. ${ }^{22-24}$

In vertebral fusion surgery, the bone graft favors consolidation. Traditionally obtained from the iliac crest of the patient, it provides mineral architecture for bone growth guidance and osteogenic factors. 11,12 $^{1,}$ The autograft of the iliac crest is considered the gold standard for spinal surgery. ${ }^{13}$ The osteoconductive and osteoinductive properties of the iliac autograft allow excellent fusion rates, in addition to low surgical cost. ${ }^{25-29}$ However, postoperative complications may occur in the place of collection, mainly pain, infection and bleeding. ${ }^{28}$

Postoperative pain at the site of bone graft collection is reported in $6 \%$ to $39 \%$ of cases. Many patients who have not undergone iliac bone graft collection may present pain in the vicinity of the posterosuperior iliac spine after the surgery, overestimating the true incidence of pain from bone graft collection. ${ }^{29}$ There is no consensus in the literature on the prevalence of pain at the collection site compared to residual low back pain in the patient, favoring the use of autologous bone graft, which is a low-cost and effective option for vertebral arthrodesis. ${ }^{29}$

In the present study, pain in the collection site of bone graft was not a limiting factor. We believe that the performance of minimal muscle disinsertion in the site of graft collection, performed in all patients, contributed to the reduction of pain. Park et al..$^{30}$ reaffirmed that the iliac bone graft has properties of osteoconduction, osteoinduction and osteogenicity, having the chemistry, structure and porosity for bone formation due to the presence of active and latent osteoblasts. Spongy bones are easily revascularized and quickly incorporated, with no concerns about disease transmission and no risk of immunogenicity. Its use brings fusion rates of $80-93 \%$ according to the aforementioned author.

Intersomatic fusion can be performed using allograft, iliac autograft, impacted local autograft, carbon fiber cage, titanium cage, PEEK cage, among others. ${ }^{31}$ Buttermann et al. ${ }^{25}$ compared clinically and radiographically the results of lumbar arthrodesis using femoral ring allograft andiliac crest autograft. They observed a pseudoarthrosis rate of $6 \%$ in cases where allografts were used and no pseudoarthrosis when the autograft was used. We believe that careful discectomy, as well as sensible preparation of terminal plates and use of iliac autograft favored the intervertebral fusion index for both groups of our study.

Autologous bone fragments obtained at laminectomy (local autograft) are often used and have similar fusion rates but are not always available in sufficient quantity. ${ }^{31-35}$ 
Martinelli et al. ${ }^{22}$ evaluated the disc height and lumbar lordosis comparing the TLIF and PLIF techniques in a retrospective study, concluding that both techniques showed benefits, with no significant difference when comparing them. In the present study, lumbar lordosis and pre- and postoperative disc height were compared. There were no statistically significant differences comparing within or between the two groups.

Lv et al. ${ }^{23}$ compared the TLIF technique with cage and impacted local autograft and concluded that there were no significant differences in clinical (ODI) and radiological (disc height and vertebral fusion) results. In addition, they concluded that the procedure without the cage has lower cost and thus the impacted bone graft is a good option for cases of single-level TLIF, especially in less developed regions. Zhang et al. ${ }^{32}$ studied spondylolisthesis in two lumbar segments operated through the PLIF technique and compared the group with cage and the group with local autograft. They observed that there was a high degree of loss in disc height in the local autograft group, concluding that the use of the cage is better for height maintenance of the intervertebral disc. The present study demonstrated divergent results since no significant differences were found in disc height between the groups. This can be explained by the fact that we used structured iliac autograft made in the form of a cage, a factor that may have contributed to the maintenance of disc height, considering that in most cases the removed local graft is fragmented and does not provide support.

Wang et al. ${ }^{33}$ compared results of the posterior arch autograft associated with a facet joint as a spacer and another group treated with a PEEK cage filled with autograft in the treatment of lumbar isthmic spondylolisthesis in adults and obtained similar clinical and radiographic results in both groups. The use of an intersomatic device in PEEK increases its cost, so a local autograft using the facet joint for intersomatic fusion was effective and accessible in the treatment of lumbar isthmic spondylolisthesis.

Wu et al..$^{34}$ studied a new intersomatic allograft device designed for TLIF, using ODI, the Visual Analogue Scale, disc height and vertebral fusion with 1-year follow-up, and concluded that there was no statistical difference in relation to disc height compared to PEEK, reaching consolidation levels of $98.2 \%$.

Studies on device sinking in vertebral bodies conducted by Choi et al. ${ }^{35}$ and Marino ${ }^{36}$ concluded that small loss of disc height and lumbar lordosis are expected in intersomatic arthrodesis and that they do not affect clinical outcomes. Le et al ${ }^{37} \mathrm{e} \mathrm{Kim}$ et al. ${ }^{38} \mathrm{con}$ cluded that loss of disc height and lumbar lordosis are related to the consolidation and accommodation of the sagittal balance of the spine, to the realization of direct decompression of the nerve root or the cauda equina and especially to the excessive sinking of the intersomatic device in the terminal plates. In our study there were no differences in relation to lumbar lordosis and disc height within or between the groups, both before and after the surgery. The limitations of the study are related to retrospective design as well as data surveying and collection. The inconsistency of data in medical records can be considered a form of measurement bias in retrospective cohort studies. Furthermore, the tests and reports in the database do not always present quality of completion and information.

\section{CONCLUSION}

We observed that the TLIF technique using structured iliac autograft may be a good option as it presents low cost and good clinical results, comparable to the synthetic intersomatic spacer.

AUTHORS' CONTRIBUTIONS: Each author contributed individually and significantly to the development of this article: RSS: performed surgeries, data analysis, writing, review and intellectual concept of the article; DEM: data analysis and writing of the article; MK: data analysis and writing of the article; ICES: data analysis and writing of the article; NA: intellectual concept and critical review of the article; MW: intellectual concept and critical review of the article. All authors approved the final version of the manuscript.

\section{REFERENCES}

1. Mobbs RJ, Phan K, Malham G, Seex K, Rao PJ. Lumbar interbody fusion: techniques, indications and comparison of interbody fusion options including PLIF, TLIF, MI-TLIF, OLIF/ATP, LLIF and ALIF. J Spine Surg. 2015;1(1):2-18.

2. Friedly J, Standaert C, Chan L. Epidemiology of spine care: the back pain dilemma. Phys Med Rehabil Clin N Am. 2010;21(4):659-77.

3. Eck JC, Sharan A, Ghogawala Z, Resnick DK, Watters WC 3rd, Mummaneni PV et al. Guideline update for the performance of fusion procedures for degenerative disease of the lumbar spine: part 7: lumbar fusion for intractable low-back pain without stenosis or spondylolisthesis. J Neurosurg Spine. 2014;21(1):42-7

4. Dickman CA, Fessler RG, Macmillan M, Haid RW. Transpedicular screw-rod fixation of the lumbar spine operative technique and outcome in 104 cases. J Neurosurg. 1992;77(6):860-70.

5. Pradhan BB, Nassar JA, Delamarter RB, Wang JC. Single-level lumbar spine fusion: a comparison of anterior and posterior approaches. J Spinal Disord Tech. 2002;15(5):355-61.

6. Fritzell P, Hägg O, Wessberg P, Nordwall A. Chronic low back pain and fusion- a comparison of three surgical techniques. Spine. 2002;27(11):1131-41.

7. Christensen FB, Hansen ES, Laursen M, Thomsen K, Bünger CE. Long-term functional outcome of pedicle screw instrumentation as a support for posterolateral spinal fusion. Spine. 2002;27(12):1269-77.

8. Barnes B, Rodts GE Jr., Haid JRW, Subach BR, McLaughlin MR. Allograft implants for posterior lumbar interbody fusion- results comparing cylindrical dowels and impacted. Neurosurg. 2002;51(5):1191-8.

9. Harms JG, Jeszenszky D. Die posteriore, lumbale, interkorporelle Fusion in unilateraler transforaminaler Technik. Oper Orthop Traumatol. 1998;10(2):90-102.

10. Baker ADL. A Prospective, randomized study of lumbar fusion: preliminary results. In: Banaszkiewicz PA, Kader DF, editors. Classic papers in orthopaedics. London: Springer; 2014. p. 281-3.
11. Fischgrund JS, Mackay M, Herkowitz HN, Brower R, Montgomery DM, Kurtz LT. Degenerative lumbar spondylolisthesis with spinal stenosis: a prospective, randomized study comparing decompressive laminectomy and arthrodesis with and without spinal instrumentation. Spine. 1997;22(24):2807-12.

12. Talia AJ, Wong ML, Lau HC, Kaye AH. Comparison of the different surgical approaches for lumbar interbody fusion. J Clin Neurosci. 2015;22(2):243-51.

13. 13. Vigatto R, Alexandre NM, Correa Filho HR. Development of a Brazilian Portuguese version of the Oswestry Disability Index: cross-cultural adaptation, reliability, and validity. Spine. 2007;32(4):481-6.

14. P'rrmann CWA, Metzdorf A, Zanetti M, Hodler J, Boos N. Magnetic resonance classification of lumbar intervertebral disc degeneration. Spine. 2001;26(17):1873-8.

15. O'Brien M. Aids to the investigation of peripheral nerve injuries: Medical Research Council: Nerve Injuries Research Committee: his majesty $\square$ s stationery. Brain 2010;10(133):2838-44

16. Frobin WBP, Biggemann M, Tillotson M, Burton K. Precision measurement of disc height, vertebral height and sagittal plane displacement from lateral radiographic views of the lumbar spine. Clin Biomech. 1997;12(1):S1-63.

17. Cobb JR. Outline for the study of scoliosis: instructional course lectures, the american academy of orthopaedic surgeons. Instr Course Lect. 1948;5:261-75.

18. U.S. Department of Health and Human Services. Guidance document for the preparation of IDEs for spinal systems. Washington (DC): Food and Drug Administration Center for Devices and Radiological Health; 2000.

19. Wiltse LL. The paraspinal sacrospinalis-splitting approach to the lumbar spine. Clin Orthop Relat Res. 1973;(91):48-57.

20. Wiltse LL, Spencer CW. New uses and refinements of the paraspinal approach to the lumbar spine. Spine. 1988;13(6):696-706.

21. Olivier E, Beldame J, Ould Slimane M, Defives T, Duparc F. Comparison between one midline cutaneous incision and two lateral incisions in the lumbar paraspina approach by Wiltse: a cadaver study. Surg Radiol Anat. 2006;28(5):494-7. 
22. Martinelli TC, Effgen EA, Brazolino MAN, Cardoso IM, Maia TC, Jacob C Jr. Evaluation of the discal height gain and lumbar lordosis variation obtained by the techniques of transforaminal and posterior lumbar intersomatic fusion. Rev Bras Ortop. 2018;53(5):527-31.

23. Lv C, Li X, Zhang H, Lv J, Zhang H. Comparative effectiveness of two different interbody fusion methods for transforaminal lumbar interbody fusion: cage versus morselized impacted bone grafts. BMC Musculoskelet Disord. 2015;16(1):207.

24. Liu P, Liu X, Qiao X, Du W, Luo D, Zheng X. [Comparison of clinical efficacies of single segment transforaminal lumbar interbody fusion with cage versus autogenous morselized bone for degenerative lumbar spinal stenosis: a prospective randomized controlled study]. Zhonghua Yi Xue Za Zhi. 2014;94(35):2731-5. Chinese.

25. Buttermann GR, Glazer PA, Hu SS, Bradford DS. Revision of failed lumbar fusions: a comparison of anterior autograft and allograft. Spine. 1997;1(22):2748-55

26. Dimar JR 2nd, Glassman SD, Burkus JK, Pryor PW, Hardacker JW, Carreon LY. Two-year fusion and clinical outcomes in 224 patients treated with a single-level instrumented posterolateral fusion with iliac crest bone graft. Spine J. 2009;9(11):880-5.

27. Kim DH, Rhim R, Li L, Martha J, Swaim BH, Banco RJ, et al. Prospective study of iliac crest bone graft harvest site pain and morbidity. Spine J. 2009;9(11):886-92.

28. Brodano GB, Griffoni C, Zanotti B, Gasbarrini A, Bandiera S, Ghermandi R, et al. A post-market surveillance analysis of the safety of hydroxyapatite-derived products as bone graft extenders or substitutes for spine fusion. Eur Rev Med Pharmacol Sci. 2015;19(19):3548-55.

29. Sheha ED, Meredith DS, Shifflett GD, Bjerke BT, lyer S, Shue J, et al. Postoperative pain following posterior iliac crest bone graft harvesting in spine surgery: a prospective, randomized trial. Spine J. 2018;18(6):986-92.
30. Park Y, Ha JW, Lee YT, Sung NY. Minimally invasive transforaminal lumbar interbody fusion for spondylolisthesis and degenerative spondylosis: 5-year results. Clin Orthop Relat Res. 2014;472(6):1813-23.

31. Eder C, Chavanne A, Meissner J, Bretschneider W, Tuschel A, Becker $P$, et al. Autografts for spinal fusion: osteogenic potential of laminectomy bone chips and bone shavings collected via high speed drill. Eur Spine J. 2011;20(11):1791-5.

32. Zhang S, Ye C, Lai Q, Yu X, Liu X, Nie T, et al. Double-level lumbar spondylolysis and spondylolisthesis: a retrospective study. J Orthop Surg Res. 2018;13(1):55.

33. Wang G, Han D, Cao Z, Guan H, Xuan T. Outcomes of autograft alone versus $P E E K+$ autograft interbody fusion in the treatment of adult lumbar isthmic spondylolisthesis. Clin Neurol Neurosurg. 2017;155:1-6.

34. Wu W, Xu J. Friday, September 28, 2018 1:00 PM-2:30 PM abstracts: achieving lumbar interbody fusion. Spine J. 2018;18(8):S94-5.

35. Choi JY, Sung KH. Subsidence after anterior lumbar interbody fusion using paired stand-alone rectangular cages. Eur Spine J. 2006;15(1):16-22.

36. Marino JF. Subsidence of metal interbody cage after posterior lumbar interbody fusion with pedicle screw fixation. Orthopedics. 2010;33(4):226-7.

37. Le TV, Baaj AA, Dakwar E, Burkett CJ, Murray G, Smith DA, et al. Subsidence of polyetheretherketone intervertebral cages in minimally invasive lateral retroperitoneal transpsoas lumbar interbody fusion. Spine. 2012;37(14):1268-73.

38. Kim MC, Chung HT, Cho JL, Kim DJ, Chung NS. Subsidence of polyetheretherketone cage after minimally invasive transforaminal lumbar interbody fusion. J Spinal Disord Tech. 2013;26(2):87-92. 